\title{
Hearing Voices: A Corporeal Expression of Trauma in Margaret Atwood's Lady Oracle
}

\author{
Ikram Lecheheb, Samira Al-Khawaldeh * \\ Department of English Language and Literature, University of Jordan, Jordan
}

Received on: 6-9-2020

Accepted on: 1-12-2020

\begin{abstract}
The study aims at giving the clinical symptom "Hearing Voices" a literary conceptualization through an analytical reading of Margaret Atwood's Lady Oracle (1976). Shedding light on the synergy between the body, the voice, and trauma, the study specifically examines how the protagonist's childhood trauma returns through the cracks of her consciousness in a form of hallucinations and hearing ghost voices in adulthood. The study also aims to explore how Atwood problematizes the notion of hearing voices to project her protagonist's inner world. The ensuing discussion utilizes Sigmund Freud's theorization on trauma's embodiment through corporeality, as well as Cathy Caruth's emphasis on the manifestation of trauma through both the voice and the body. Also relevant is Laura Di Prete's focus on the interplay between embodied voices and speaking bodies.
\end{abstract}

Keywords: Childhood memories; Corporeality of trauma; Hearing voices; Margaret Atwood,;Lady Oracle.

\section{Introduction}

Due to the atrocities of the two World Wars, along with various conflicts, the history of trauma has evolved through contradictory theories and debates. One specific area that has recently come into focus is how human beings project the overwhelming effects of traumatizing experiences. The manifestation of trauma has not confined itself to the realm of one form. It is, rather, a specter that haunts discourses of history, literary theory, psychoanalysis, and literary criticism. Contemporary literary theorists of trauma, for instance, start questioning if trauma is exclusively expressed through narrative, writing, and language. In Testimony: Crises of Witnessing in Literature, Psychology, and History, Felman and Laub argue that, after different horrible events including the Holocaust, language is no longer valid to project traumatic experiences encountered earlier in the individual's life; for in each survivor, there is "an imperative need to tell", but "there are never enough words or the right words, there is never enough time, or the right time, and never enough listening or the right listening to articulate the story that cannot be fully captured in thought, memory, and speech" $(1992,78)$. In their studies, contemporary theorists of trauma like Kali Tal (1996), Deborah Horvitz (2000), and Dominick Lacapra (2001) indicate that there is an urgent need to

\footnotetext{
() 2021 JJMLL Publishers/Yarmouk University. All Rights Reserved,

* Doi: https://doi.org/ 10.47012/jjmll.13.4.11

* Corresponding Author: samalkhawaldeh@gmail.com
} 
Lecheheb, Al-Khawaldeh

look for other alternatives which can enunciate different traumas; such as corporeality and the body as a form of projecting unspeakable experiences.

This study, therefore, is an attempt to highlight the correlation between the body, hearing voices and trauma as they appear in Atwood's Lady Oracle. Specifically, it is devoted to investigate how soma reflects the character's traumatic memories through hallucinations and hearing voices. Hallucinations and hearing voices are treated as a form and literary device through which the protagonist's earlier traumatic events are enunciated. The study deals with the following questions: What do psychoanalysts have to inform us on the connection between soma, hearing voices, and trauma? How can this be applied to the traumatized protagonist in Atwood's Lady Oracle? Finally, what are the thematic functions and the structural purposes that Atwood seeks to fulfill in utilizing this form of trauma? To deal with these questions, the study engages with various theoretical propositions on trauma and its connection with hearing voices, particularly Freud and Caruth's psychoanalytic studies in the domain of trauma's manifestation through corporeality. The study, additionally, refers to Laura Di Prete's postulation on the "embodied voice" (2006, 138) and the "speaking body" (2006, 161) in which, as she explains, "Conceptualized voice, and body function synergistically to force trauma into representation, to make it accessible in the recognition of its expressive limits, and to explore viable forms of working through" (Di Prete 2005, 484).

Atwood's Lady Oracle deals with the life of the character Joan Foster. Foster narrates events retrospectively to reflect her feelings and her childhood. In a fragmented manner, Foster indicates that she fabricates different stories about herself under different names: Joan Delacourt and Louisa K. Delacourt in order to forget her traumatic past. Jerome Rosenberg suggests that Joan Foster's life is, "A poignant anatomy of childhood, terror, and alienation" $(1984,112)$. To problematize Joan's situation and her search for a whole self and identity, the author, throughout the novel, incorporates the motif of the quest for self-discovery, depicting Joan as always on the balcony looking down. In the first page of the novel, Joan says: "[She] had always been fond of balconies" (3). Joan declares, "I was safe, I could begin again, but instead I sat on my balcony" (6). Here, Atwood employs the balcony setting as metaphor; the way Henry James does in The Ambassadors; where, according to critics, it "embodies a major discovery" and "charts the rise and fall in [the character's] sense of freedom" (Gibson 1951, 298). Likewise, in the context of Lady Oracle, one may discern that the balcony emblematizes Joan's attempt to distance herself from the traumatic memories that haunt her, and to figure out how to get rid of them.

There was someone outside, on the path. I could hear stealthy footsteps, coming down towards me. A shoe slid on gravel. The footsteps paused [...] I realized how visible I must be, back-lit behind the picture window. I froze, listening, then turned out the light and crouched down behind the table [...] for a long time I huddled behind the table, listening for a sound, feet coming toward me, feet retreating [...] it was nerves I told myself. I would have to watch that. I climbed into my bed, taking my fotoromanzo with me to calm myself down. (204 -05)

It is worth noting that the history of hearing voices and hallucinations has baffled psychoanalytic researchers. Through different psychoanalytic studies, it is shown that there is no concept labeled 


\section{Hearing Voices: A Corporeal Expression of Trauma in Margaret}

Atwood's Lady Oracle

"Hearing Voices." The latter is rather a symptom, which is associated with mental disorders. To begin with, hearing voices and hallucinations are traced in the studies of Emil Kraepelin, a German psychiatrist, who has his significant contribution to this field of research. Kraepelin embraces and develops Bénédict Augustin Morel's concept of dementia praecox throughout the different editions of Psychiatry: A Textbook for Students and Physicians. In the fifth edition, for instance, Kraepelin defines dementia praecox as "A name [he has] given to the development of a simple, fairly high- grade state of mental impairment by an acute or sub-acute disturbance" (Kraepelin 1896, 426). In the same edition, Kraepelin extends Morel's description of dementia praecox by providing examples of disturbances such as Lack of concentration, self- reproach, fears for future, and the lack of inner consistency in speech and behavior (Kraepelin, 1896, 425). Kraepelin shows that, in the case of dementia praecox, individuals lose touch with reality. Noll highlights that, in the sixth edition, Kraepelin gives a more detailed definition of dementia praecox, "An illness that begins with an episode marked by confusion, depression, headaches, delusions (both fluid and fixed), and auditory hallucinations (usually voices) and soon produced gaps in attention, incoherent speech, and bizarre actions" (Noll 2011, 4). Interestingly, Kraepelin sees hallucinations and hearing voices as the most striking symptoms of dementia praecox.

There is also Carl Gustav Jung and Paul Eugen Bleuler who contribute to the field of dementia praecox in their studies. Jung, for instance, provides a critical and a theoretical survey on the psychology of dementia praecox in his book The Psychology Of Dementia Praecox (1907). Using the 'word association test', Jung deals with different cases that suffer from dementia praecox. Essentially, Jung makes a detailed comparison between hysteria and dementia praecox asserting that, "The associations in dementia praecox are characterized by the presence of an abnormally strong complex" (Jung 1960, 110). Bleuler and Jung co- authored a paper entitled "Complexes and Aetiology in Dementia Praecox" (1908), in which they shed light on dementia praecox and its symptoms which are resulted from different complexes. Bleuler embraces Jung's concept of complexes giving it a detailed description in his essay "Consciousness and Association" asserting that,

Independently of the conscious personality, wishes and fears regulate ideas to their liking and combine them in a compact complex, whose expressions emerge as "hallucinations"; these appear to be so consequential and deliberate that they simulate a third person But it[...] is merely a piece of the split-off personality; it represents aspirations of this personality which would otherwise be suppressed. (Bleuler 1918, 279)

In 1911, Bleuler writes his Dementia Praecox, or Group of Schizophrenias, in which he highlights that trauma is not a disease. It is rather an accumulation of conflicts that have psychological effects on the subject. He mentions, "And not infrequently, after a careful analysis, we had to pose the question whether we are not merely dealing with the effect of a particularly powerful psychological trauma on a very sensitive person rather than with a disease in the narrow sense of the word" ( Bleuler 1950, 300). In his book, Bleuler specifies that there are other symptoms which can be involved under the category of 
Lecheheb, Al-Khawaldeh

dementia praecox. Bleuler proposes that deterioration not always leads to eventual death in the case of dementia praecox (Gilman 2019, 213). In the same work, Bleuler coins the term schizophrenia as a replacement of Kraepelin's dementia praecox. Nancy Andreasen and William Carpenter note that Bleuler's book focuses on the symptoms of schizophrenia as a mental disorder,

For Bleuler, the most important and fundamental symptom was a fragmentation in the formulation and expression of thought, which he interpreted in the light of the associational psychology prevailing at the time and referred to as 'loosening of associations.' He renamed the disorder 'schizophrenia' to emphasize splitting of associations as the most fundamental feature of the disorder. (Andreasen and Carpenter 1993, 201)

From Bleuler's perspective, schizophrenia or the split mind is characterized by changes in perception, thoughts, and behavior. He essentially refers to schizophrenia's symptoms which are related to the person's inability to distinguish between what is real and what is not. Bleuler argues that disturbances in association, hallucinations, and delusions are the main symptoms of schizophrenia. In dealing with hearing voices, Bleuler also maintains that hearing voices is associated not only with schizophrenia but also with trauma as a separate disorder. In A Textbook of Perioperative Care, Kate Woodhead and Paul Wicker highlight that Bleuler emphasizes that individuals may have hallucinations which are "Commonly auditory, but may be visual or experienced through a smell, taste, or touch, or indeed any combination of the senses, something giving the individual a complete sensory experience that is more real to them" (Woodhead and Wicker 2005, 358). The aforementioned quote indicates that traumatized subjects hear ghost voices as an expression of their trauma. Consequently, Bleuler's study, on the one hand, highlights the notion of hearing voices and its connection with schizophrenia; and, on the other hand, it sets the stage for new studies that spotlight on the connection between trauma, as a separate disorder, and hearing voices.

In literary criticism, critics use the concept of dementia praecox to identify the nature of the narrators' mental condition in works of fiction. In The Abnormal Personality through Literature (1966), Alan Stone and Sue Smart Stone give insight into different psychological disorders; namely dementia praecox, or what is later on called schizophrenia, utilizing works of fiction. In other words, the authors shed light on the abnormal behavior of the characters through analyzing a wide range of writers as Nikolai Gogol, Fyodor Dostoevsky, Herman Melville, Edgar Allan Poe and others. Following a similar line of analysis, the present study deals with trauma as a separate disorder, showing how Atwood's protagonist is a traumatic subject whose trauma molds her actions and behavior. The study additionally focuses on how Joan expresses her trauma through corporeality; particularly through hearing ghost voices.

In Lady Oracle, Atwood depicts how in the development of Joan's trauma, her protagonist exhibits gross swings in mood, sometimes losing interest in the external world altogether, resulting in her decision to commit suicide. Atwood opens the novel with an episode, in which the traumatic protagonist, Joan, decides to put an end to her previous life after being depressed, fragmented, and alienated due to living different traumatic life events, 


\section{Hearing Voices: A Corporeal Expression of Trauma in Margaret Atwood's Lady Oracle}

I planned my death carefully; unlike my life, which meandered along from one thing to another, despite my feeble attempts to control it. My life had a tendency to spread, to get flabby, to scroll and festoon like the frame of a baroque mirror, which came from following the line of least resistance. I wanted my death, by contrast, to be neat and simple. (3)

This indicates that Atwood uses the image of death metaphorically to highlight the narrator's strife to erase the past memories out of her consciousness through different ways as escaping into a fantasy world, writing gothic and romantic works as a shield or a safeguard against her traumatic life. The narrator writes, "You cannot change the past, Aunt Lou used to say. Oh, but I wanted to; that was the one thing I really wanted to do" (6). Through inventing different stories, both the instability of the narrator's psyche and her unreliability in narrating her story are conveyed. Each story of the narrator becomes a fantasy for the reader. To borrow the words of Robert Lecker, each "I" in the novel is "a lie" $(1981,194)$.

While tracing the history of hearing voices, it is essential to refer to Sigmund Freud's contribution to the field. Throughout his studies, Freud asserts that the appearance of a mental disorder is connected with the return of the repressed. He charts the psychoanalytic implicit connection between the body, the return of repressed past memories, and the voice. Freud's references to the notion of hearing voices are few as he does not construct a systematic theory of hallucination and hearing voices. He, rather, deals with psychosis and considers hysteria, obsessional neurosis, and hallucinatory confessions as defence mechanisms. Freud maintains that hallucinations are a product of unconscious conflicts that the individual cannot control. As typical of Freud, his references to hallucinations and hearing voices are based on the observation of different cases that are examined in Studies in Hysteria (1895): "The voices owed their origin to the repression of thoughts which [...] were in fact self- reproaches about experiences that were analogous to childhood trauma. The voices were accordingly symptoms of the return of the repressed" (2004, 305).

In Beyond the Pleasure Principle (1920), Freud sheds light on repetition compulsion showing that ungraspable, overwhelming experiences haunt traumatized individuals. To reinforce his argument, Freud reads Torquato Tasso's La Gerusalemme Liberata, in which Tancred mistakenly killed his beloved Clorinda. As time runs, Tancred hears the voice of Clorinda, "Whose soul is in the tree [...] complaining that he has wounded his beloved again" (Freud 2003, XIV). Freud's work illustrates that trauma can be manifested again in a form of hearing repetitive voices; that is, Freud indirectly shows the existing bond between the return of the repressed, repetition compulsion, and the voice to "Conjure up what has been forgotten and repressed"' (Freud 2003, 37).

It should be pointed out that Cathy Caruth is one of the leading figures who try to give emphasis to the study of hearing voices and hallucinations. Caruth refers to Freud's concept of repetition compulsion indicating that traumatized individuals experience a cyclical reliving of the past because of the haunting nature of unspeakable memories (Caruth 1996, 4). In "The Wound and the Voice" the introduction to her Unclaimed Experience: Trauma, Narrative, and History (1996) Caruth refers to Freud's reading of 
Tancred's scene. In her introduction on trauma and the voice, Caruth indicates that whenever there is a trigger, earlier traumatic memories seep through the cracks of consciousness in the form of hearing voices, leading the traumatized subject to encounter and to put terms with the past.

In highlighting the synergy between the body, the voice, and trauma, it is significant to refer to Laura Di Prete's book Foreign Bodies: Trauma, Corporeality and Textuality in Contemporary American Fiction. In it, the author deals with corporeality's representation of trauma through the voice which is "a mode of telling that acknowledges an indissoluble bond between voice, body, trauma, and corporeality" (2006, VI). Di Prete further claims that trauma returns to consciousness through the interplay between an embodied voice and a speaking body. In other words, past memories manifest themselves in a form of voices and specters. The study, therefore, brings Freud, Caruth, and Di Prete's orientations in connecting the body, the voice, and trauma in the analysis of Atwood's Lady Oracle.

Recent interdisciplinary studies shed light on the literary conceptualization of clinical and psychoanalytic symptoms and concepts in literary criticism. Esther Rashkin, for instance, is a literary critic concerned with the presence of clinical symptoms and concepts in works of fiction. In Family Secrets and the Psychoanalysis of Narrative, (1992) Rashkin puts her theory into action using Nicolas Abraham, and Maria Torok's work on the phantom and applying it to works of fiction including Joseph Conrad's The Secret Sharer. Chiefly, in her "Reading the Mind, Reading the text, Reflective Functioning, Trauma and Literature, and the Task of the Psychoanalytic Critic" (2011) Rashkin makes a reference to a recent interdisciplinary conference on trauma, narrative, and psychoanalysis entitled "Trauma; Intersections among Narrative, Psychoanalysis, and Neuroscience" (2010), in which different questions are raised including "bringing a literary perspective to bear on clinical research" (Rashkin 2011, 37-38). Rashkin contributes to the field of a literary reading of psychoanalytic symptoms and concepts by accentuating that it is the role of the psychoanalytic critic to read the mind of the characters as they are shown in literary works.

In showing the studies that conceptualize clinical concepts, it is essential to refer to the theory of the mind. The latter is a new area of research that is traced back in the Theory of Mind and Literature (2011), in which Paula Leverage and other critics underline the connection between psychoanalysis and literature using the concept of "theory of Mind," which is associated with, "A relatively new area of investigation that brings an understanding of cognitive scientific studies and neuroscience to the reading and interpretation of literature" (3) and as "A critical tool" for reading the characters' state of minds in works of literature ( Leverage et al. 2011, 1). Although the correlation between trauma and hearing voices has strong psychoanalytic support, to psychoanalytic theorists, it remains no more than a symptom. Hence, as an interdisciplinary attempt, the study seeks to provide a literary conceptualization of hearing voices as a clinical symptom. Through the analysis of Atwood's novel, the study emphasizes how the author problematizes hearing voices as a literary device, which is not entirely new.

There are different references to hearing voices and hallucinations in literature including Shakespearean plays. In 1834, the Russian author Gogol also provided a detailed description of a schizophrenic person in his short story "Diary of Madman" in a way his protagonist hears auditory hallucinations that the dogs talk with each other. Don Delillo's The Body Artist (2001) is another literary 


\section{Hearing Voices: A Corporeal Expression of Trauma in Margaret \\ Atwood's Lady Oracle}

example, in which the author focuses on the return of Lauren's trauma of losing Rey, her husband, in a form of voices and a foreign body. The memory of Rey returns to Lauren through Mr. Tuttle as a phantom which appropriates Lauren's voice, "She began to understand what she was hearing [...] It was not outright impersonation but she heard elements of her voice, the clipped delivery, the slight buzz deep in her throat, her pitch, her sound" (50).

\section{Joan Foster's Traumatic Memories:}

From a psychoanalytic perspective, the study hypothesizes that Joan's childhood memories return to her consciousness to be manifested in a form of hallucinations and hearing voices. In "Hearing Voices" Bettina Thraenhardt asserts that,

Some effected people may hold too much on the inside. Sufferers have often experienced some kind of trauma as a child such as neglect, abuse, rape, or a severe accident. Many then suffer from unresolved conflicts or find themselves in situations that overwhelmed them. In these cases, verbal hallucinations may serve as signal. (Thraenhardt 2007, 76)

In a fragmented manner, Joan revitalizes the traumatizing events that hurt her. Broadly speaking, her relation with her mother is the most important reason for the narrator's trauma. As the mother lives an unhappy life with her heartless husband who left her pregnant to fare for herself, the matriarch becomes a dominating person who imposes her thoughts upon her daughter. Accordingly, what characterizes Joan's connection with her mother is that there are no ties between them in a period the child needs the mother as a source of empowerment and a model figure for building Joan's personality. Throughout the narrative, Joan repetitively refers to her poor connection with her mother,

I can never remember calling her anything but mother, never one of those childish diminutives, I must have, but she must have discouraged it. Our relationship was professional early. She was to be the manager, the creator, the agent; I was to be the product. I suppose one of the most important things she wanted from me was gratitude. She wanted me to do well, but she wanted me to be responsible for it. (68)

Since the mother suffers from restrictions in society, she decides to satisfy the society's patriarchal attitudes through making Joan a model feminine person without taking into considerations her daughter's feelings and needs. Joan, however, defies and refuses her mother's mentality and dominance, "I did not like her. She was always trying to tell me how to run my life" (96). In order to reject the mother's demands, the narrator chooses over - eating as a solution for her mother's unbearable attitudes, "I ate to defy her, but I also ate from panic" (80). After years of his departure, the father comes back again to live with his family. The uncomfortable relation between the parents is directly shown in front of Joan, "It was almost a direct line to the kitchen where they had most of their fights; or rather my mother had them" (79). These painful memories come again to haunt Joan during adulthood. 
Lecheheb, Al-Khawaldeh

As time runs, it becomes clear that Joan's body becomes the ground where the matriarch emotionally abuses the child who cannot control her eating, "By this time I was eating steadily, doggedly, stubbornly, anything I could get. The war between myself and my mother was on in earnest; the disputed territory was my body" (71). To borrow Hutcheon's words, the narrator overeats as a way of "defiance and escape" (Hutcheon 1988, 24). Because of Joan's fatness, the mother forces her daughter to participate in a dancing school. Over the course of time, Joan decides to stop going to the dancing school due to her being overweight, and the humiliating episodes that she faced. Joan notes, "The worst thing was that I still did not understand quite why this was being done to me, this humiliation disguised as a privilege" (49). The mother, however, does not surrender to Joan's refusal to get rid of her excessive weight; this is why she decides to send her to a psychiatrist.

At the heart of the mother's attempts to shape Joan's body, the mother starts, in every turn, humiliating her and broadening the gap between her and her daughter using hurtful words. The mother, for instance, sees Joan's birth as an accident "I would hear her call me an accident" (80). In one of the incidents in which Joan has made a mistake, the mother comments, "Sometimes I think you have not got a brain in your head" (81). The mother adds, "If I looked like you I would hide in the cellar" (91). In one of Joan's happy days, the mother was without feelings and she did not show any support to Joan. The latter narrates her painful memory in the Canadian National Exhibition, "My mother did not hold me by the hand, there were her gloves to think of" (92). This incident is the climax through which Joan realizes the attitudes of her heartless mother. In this perspective, the narrator starts distancing herself from her mother because, "The secret that [Joan] alone knew: [her] mother was a monster" (68). On this basis, Atwood employs the metaphor of labyrinth to depict Joan's mental state after arriving at the conclusion that her mother has no feelings towards her.

Interestingly, numerous psychoanalytic theorists discuss the mother-infant relationship: Freud and Jacque Lacan are cases in point. Specifically, the mother- daughter relationship has gained its space in contemporary psychoanalytic studies including Jessica Benjamin (1988), Janice Doane and Devon Hodge (1992), and Jacqueline Rose (1996), in which the mother is depicted as an object of fantasy. Additionally, Luce Irigaray (1991) is another psychoanalyst who adds her contribution to the etiology of the motherdaughter connection. Irigaray insists that the abused daughter distances herself from the mother as a part of "Defence mechanism" (Irigaray 1991, 41). In theorizing about the mother - daughter connection, Irigaray uses certain symbols to describe the mother figure such as "The devouring mouth" (41), "Devouring monster" (67), and "Phallic threat" (41). Finally, Melanie Klein's Some Reflections on the Oresteia: Envy and Gratitude and Other Works 1946 - 1963 is another study, in which the psychoanalyst puts emphasis on the mother- daughter relationship using Greek myth. Klein particularly claims that the mother - daughter relationship is full of "Grievance, a hate, [...], destructive impulses especially strong envy" (Klein 1997, 183; 188).

A reading of Irigaray and Klein's contributions brings us into the analysis of Joan's non-intimate relationship with her mother. Due to the mother's bad treatment, the narrator distances herself from her mother as a part of defence mechanisms. In order to portray Joan's bad connection with her mother, Atwood uses various images including the "shadow" (69) and "the monster" (68). Because of her 


\section{Hearing Voices: A Corporeal Expression of Trauma in Margaret Atwood's Lady Oracle}

loneliness and alienation, Joan eventually wishes that Aunt Lou is instead her mother, "In one of my daydreams I used to pretend Aunt Lou was my real mother" (91). She finds a relief in her connection with Aunt Lou simply because, "She actually seemed interested in what [Joan] had to say, and she did not laugh when [Joan] told her I wanted to be an opera singer" (85).

Predominantly, the relationship with men, namely Paul, Arthur, and the Royal Porcupine contributes to Joan's alienation and the return of her painful memories. During adulthood, as a way to forget the lack of contact and the lack of intimacy with her mother, Joan falls in love with Paul who is seen as another cause that triggers her traumas to return to the surface. Paul emotionally abuses Joan since he sees her as a mistress. Later on, Joan marries Arthur who conforms to the restrictions of the patriarchal society. He is a possessive person who forces her to take birth control pills. As time runs, Joan realizes that her husband strives to turn her into a domestic servant. In her narrative, Joan highlights her husband's happiness during her failures in cooking, "Arthur enjoyed my defeats. They cheered him up. My failure was a performance and Arthur was the audience" (228). Joan's marriage proves to be a failure especially after discovering that Arthur is in a relationship with Marlene. Even though Joan is alienated from her surroundings, she finally decides to free herself from Arthur's dominance because she imagines him as a wife- killer, and then she implements her escapist project.

In The Divided Self: An Existential Study in Sanity and Madness (1960), Ronald D. Laing focuses on schizophrenia and concepts of schizoid and schizophrenic from phenomenological and existential perspectives. He, basically, notes that due to various stressful life events, the individual becomes depersonalized and starts creating different identities through the interplay between the true self and the false - self system. The psychiatrist also refers to cases of the self and the false self-system in the works of Franz Kafka and Søren Kierkegaard. Laing describes schizoid conditions as follows,

The term schizoid refers to an individual the totality of whose experience is split in two ways: in the first place, there is a rent in his relation with his world and, in the second, there is a disruption of his relation with himself. Such a person [...] experiences himself in despairing aloneness and isolation; moreover, he does not experience himself as a complete person but rather as split in various ways, perhaps as a mind more or less tenuously linked to a body, or two or more selves. (Laing $1960,15)$

After all painful traumatic events, Joan decides to escape not only from her miserable relations with her mother, her husband, her lover, the Royal Porcupine, but also from her fragmented self. From Laing's approach, Atwood's protagonist exhibits signs of schizophrenia which are shown in her splits between the inner self , the true self and what Laing calls " The false self- system" (74) as a defence mechanism, or to

"Transcend the world and hence to be safe" (80). In order to forget the past, Joan undertakes the project of having multiple names. Besides, she starts writing gothic romances and feminist poetry as a sort of resisting the patriarchal society. She, essentially, undergoes a fake suicide, and she finally flees because 
she "Needed something more familiar. A place with no handholds, no landmarks, no past at all: that would have been too much like dying" (8).

The narrator, subsequently, strives to re-direct her life in an organized manner, yet the past resists disappearing. As a clarification, in her narrative, Joan keeps using the word past showing some panic and fear, "The panic I had not allowed myself to feel for the past week rolled in an icy-grey wave back over my head, carrying with it shapes of my fear, a dead animal, the telephone breath [...], faces formed, and distinguished in my head" (12). Joan adds, "I wanted to forget the past, but it refused to forget me; it waited for sleep, then cornered me" (233). It is interesting to observe that Joan's past traumatic memories concerning her connection with men not only have devastating ramifications on her psyche, but they return back to her consciousness during adulthood. Specifically, the memories of Joan's fatness and the memories of her connection with her mother are the main focus of this study as they have a haunting nature in Joan's present. In "Transformation of the Protagonist in Margaret Atwood's Lady Oracle" (2012) Vijeta Gautam highlights,

Margaret Atwood gives us a very self-determined and active mother and a daughter whose life and writing are haunted by the mother [...] In Lady Oracle, Atwood states that Joan's interaction with her mother in childhood or the lack of it has profound impact which can last into her adulthood. (Gautam 2012, 235)

\section{The Enunciation of Joan's trauma through Hearing Voices:}

Due to the fragility of her consciousness, her alienation, and her fragmentation, the narrator's past memories return back to the surface in a form of hallucinations and hearing voices. Larkin and Morrison indicate that whenever traumatized subjects are alienated and isolated, they cannot cope with trauma, and cannot accept the notion of hearing human voices, "The inability to cope with the voices might result in a number of secondary reactions. They might isolate themselves or stay in bed to try to avoid performing the aggressive acts of voices command them to do" (2006, 164). Based on Larkin and Morrison's perspective, Joan, at the beginning, refuses to confess that she hears voices, yet she shows her fear and anxiety towards the voices she hears.

Despite the fact that individuals forget about their earlier traumatic past life events, traumatic memories find route to consciousness to manifest themselves in a form of voices. In "The Auditory Hallucination: A phenomenological Survey" (1996), Tony Nayani, and Anthony David argue that these voices converse with traumatized individuals commanding them to do certain things, and reminding them of their previous traumatic events. Additionally, Nayani and David accentuate that hearing voices involve a number of sounds including "talking, laughing, crying, whispering, singing, and humming as well as environmental or elemental sounds such as blowing, rustling, rattling, music, bangs, and clicks" (qtd. in McKague et al. 2012, 2). In using Nayani and David's argument, the study accentuates that due to the commanding nature of the voices, Joan rapidly surrenders to these voices "It struck me that I would spent too much of my life crouching behind closed doors, listening to the voices on the other side" (369). She adds that she starts believing their existence, "When you started hearing voices you were in trouble, especially if you believed them" (366). In another incident, the narrator highlights that the voices are 


\section{Hearing Voices: A Corporeal Expression of Trauma in Margaret \\ Atwood's Lady Oracle}

haunting her to conjure up something that she refuses to acknowledge, "I could hear voices. Sometimes there were a lot of voices, sometimes only two, they were talking about me, discussing me, and as I listened I would realize that something very bad was going to happen" (232).

Due to her fear of these human voices, Joan acknowledges that her mother's attitudes have harmed her emotionally, and psychologically as well. As time runs, Joan cannot get rid of the overwhelming memories of her mother. She sees her in nightmarish dreams, "One of the bad dreams about my mother was this. I would be walking across the bridge and she would be standing in the sunlight on the other side of it" (66). Essentially, the mother's memories manifest themselves to Joan in her dreams,

If someone had to come back from the other side to haunt me, I thought, why could not it be Aunt Lou? [...] Whereas my mother [...] why did I have to dream about my mother, have nightmares about her, sleepwalk out to meet her? My mother was a vortex, a dark vacuum; I would never be able to make her happy. Or anyone else. Maybe it was time for me to stop trying (358).

In the realm of projecting the connection between the body, the voice and trauma, Freud uses the metaphor of the foreign body. From Freud's orientation, the foreign body is associated with the materialization of past memories in a form of a phantom that appropriates the traumatized individual's voice to trigger the subject to work through repressed memories, "The psychical trauma- or more precisely the memory of it, operates like a foreign body which must still be regarded as a present and effective agent long after it has penetrated (Freud 2004, 10). In "Hearing Voices: May Be Normal But Happens Most Commonly in Schizophrenia and Alcoholic Hallucinations" (1989), John Charles Cutting shows that schizophrenic individuals not only hear voices, but they declare that these voices materialize in the image of a human being. Cutting declares that "A patient with a severe personality disorder will report experiencing a stereotyped voice, usually of someone who is the focus of their anger; the patient may communicate with the voice and claim to see the person at the same time" (Cutting1989, 769).

In their work, Abraham and Nicholas Rand (1987) coin the concept of "the phantom" indicating that repressed memories haunt the traumatized individual in a form of a phantom "To objectify, even under the guise of individual or collective hallucinations" (Abraham and Rand 1987, 287). From the critics' perspective, the phantom appears to the consciousness of the individual to break certain silences, gaps, and cryptic constructions buried in the unconscious. Abraham and Rand go a step further exploring the relation between the voice and trauma. They show that the stranger embodies the silences and the gaps. These latter appear in the phantom's voice and words, "The phantom's periodic and compulsive return works like a ventriloquist, like a stranger within the subject's own mental topography" to work through the subject's past memories (Abraham and Rand 1987, 289-90).

In using Freud, Cutting, Abraham, and Rand's argument that the phantom or the foreign body is a medium through which trauma is enunciated, the study highlights that there is a representational shift in articulating trauma from hearing voices to a phantom. Through analyzing Lady Oracle, the study shows that the insistent resurrection of Joan's mother's memories through hearing voices turns into a phantom. 
Lecheheb, Al-Khawaldeh

In one of the incidents, Joan expresses that her mother's maltreatment haunts her not only through hallucinations and hearing voices, but also through a specter,

I woke up in the middle of the night. I could hear footsteps outside my window, on the terrace down below. Now there was a scraping noise: someone was climbing the trellis! Had I locked the window or not? I did not want to get out of bed to see [...] it was only my mother. She was dressed in her trim navy-blue suit with the right waist and shoulder pads [...] what do you want? But she did not answer. She stretched out her arms to me [...] She wanted us to be together. (357)

In Lady Oracle, the narrator describes her mother as "A monster" in her dressing table mirror (68). She adds that the mother's image haunts her, especially "The curious double mouth, the real one showing through the false one like a shadow" (69). Atwood employs different expressions including a threeheaded monster, a rotting albatross, a vortex, a dark vacuum to aptly depict Joan's fear of her mother in both her childhood and adulthood. Despite the mother's death, Joan is still being afraid of her mother during adulthood. Abraham writes, "The theme of the dead who- having suffered repression by their family or society, cannot enjoy, even in death, a state of authenticity" (Abraham 1987, 287). This repression, he adds, returns in a form of a phantom "Whatever its form, is nothing but an invention of the living" (1987, 287). Joan asserts that her mother's memories cause her to live frightening nights. Repetitively, Joan notes that she is awake when her mother comes to her, "She would come very close that time, she would almost done it. She would never really let go of me. It had been she standing behind me in the mirror; she was the one who was waiting around each turn, her voice whispered the words" (358).

In the background of highlighting the causes that lay behind Joan's schizophrenia, it is essential to refer to Joan's fatness and how others treat her as a fat lady even her mother. Joan's overweight has affected her social life. In her adulthood, the memory of the fat lady in pink who walks the tightrope haunts Joan. During her stay abroad, the narrator hears strange voices in the house, "I thought I heard someone in the next room. I listened careful not to make a ripple: there were definite foot-steps, crossing the main room and heading towards my bedroom. I froze in the bathtub; I went rigid with fear. For a moment, I lay there like a giant popsicle" (310-11). This indicates that Joan's memories materialize in a form of a stranger or what Freud calls the foreign body (6).

In her reading of Tasso's scene, Caruth goes a step further through linking the body, the voice, and trauma. The critic shows that one cannot deal with the voice inseparably from the body since the voice is "released through the wound" (Caruth 1996, 2). Caruth implicitly maintains that through the insistent nature of the voice, trauma gradually materializes in the form of a foreign body. On the one hand, Caruth directly maintains that Clorinda's voice haunts Tancred. On the other hand, Caruth implicitly indicates that through the insistent nature of Clorinda's voice, Tancred's trauma materializes in a corporeal form. Foremost, Caruth refers to Freud's argument highlighting that voice is a medium of projecting traumatic memories "It listens to a voice that it cannot fully know but to which it nonetheless bears witness" (qtd. in Caruth 1996, 9). In using the concepts of the embodied voice and the speaking body, Di Prete criticizes 


\section{Hearing Voices: A Corporeal Expression of Trauma in Margaret Atwood's Lady Oracle}

Caruth's touch in projecting trauma through the foreign body. Di Prete indicates that the projection of trauma through the foreign body remains a blind spot in Caruth's postulations on trauma,

Caruth fails to recognize the other essential dimension [foreign body] through which this telling takes place. Not only Clorinda's voice and the unwilling repetition of the act of wounding return to haunt Tancred, but also the insistent reappearance of Clorinda's transformed, transfigured, and thus unrecognizable body. (Di Prete 2006, 13)

In Lady Oracle, Atwood focuses on the interplay between the fat lady's voice and her manifestation in a foreign body as well. In this respect, Joan declares, "My old dreams about the Fat Lady returned, only this time she would be walking across her tightrope, in her pink tutu, and she would fall, in slow motion" (273). In another incident, Joan indicates that her fatness haunts her in materialized body, "It was irrational, but I had the feeling that there was someone inside the flat, sitting in the chair by the window, waiting for me" (27). She adds, "The outline of my former body still surrounded me, like a mist, like a phantom moon" (233). As the novel goes on, it becomes evident that the fat lady has controlled the narrator's life, "For a moment, she hovered around me like ectoplasm, like a gelatin shell; my ghost, my angel; then she settled and I was absorbed into her" (349). During her stay in her room, Joan finally recognizes that the fat lady is present whenever she is isolated from social contact, "I would see someone in the mirror, or rather in the room, standing behind me. I was sure of it" (240).

In different psychoanalytic studies, mirrors are associated with the individual's psychic disorder and fragmentation between the self and the double. In his essay, "The Mirror Stage as Formative of the Function of the I as Revealed in Psychoanalytic Experience" as a part of his book Écrits, Lacan postulates that every individual goes through a phase called the mirror stage through which infants form their identities. From Lacan's perspective, the mirror stage is a part of the child's behavior in a way the infant searches for the real self. Lacan adds that the mirror stage is a "Jubilant assumption of specular image by the child at the infans stage, would seem to exhibit in an exemplary situation the symbolic matrix in which the I is precipitated in a primordial form, before it is objectified in the dialectic identification with the other" (2).

In Atwood's Lady Oracle, the mirror is a dominant metaphor. Atwood employs the metaphor of the mirror to highlight how Joan differentiates between her true self and her reflection in the mirror. In her childhood, Joan forms an identity based on an image. From Lacan's perspective, in the pre mirror stage, Joan has a non-unified foundation of herself. In other words, Joan's body in the pre mirror stage is identified as "bits and pieces" (Lacan 1977, 97). In using Lacan's argument, the study shows that Joan's behavior consists of mainly her searching for the real self which is trapped inside the mirror. Throughout the novel, Atwood highlights that Joan is fascinated by mirrors. She is preoccupied with mirrors and reflections. Joan repetitively mentions that she "had polished [mirrors] with [her] love and expected them to shine, brightly enough to return [her] own reflection, enhanced and sparkling" (308- 09). In The Phenomenology of Perception (2002), Maurice Merleau Ponty highlights, "I am no longer what I felt 
Lecheheb, Al-Khawaldeh

myself, immediately to be; I am that image of myself that is offered by the mirror" (Ponty 2002, 76). Almost every scene of Joan's narration depicts her connection with mirrors. Mirrors appear in her room, her bathroom, the dancing room, and other places. Because of this, Joan is surrounded by her own reflection, and she cannot embrace her real self because her understanding of it remains in the pre- mirror phase. As a clarification, whenever, she finds a chance, Joan "Went again into the mirror" (240). In her bathroom, Joan declares that "[She]close[s] the bathroom doors, drape[s] [her]self in silk or velvet and get out all the dangly gold earrings and chains and bracelets [she] could find. [She] would drape [her] self with perfume, take off [her] shoes and dance in front of the mirror twirling slowly around, waltzing with an invisible partner" (21).

Atwood uses the mirror to scrutinize Joan's quest for a coherent self. Mirrors, in Lady Oracle, reflect the presence of moments of the narrator's psychosis. During episodes of psychological disturbance, Joan encounters a problematic situation, in which she cannot know her real self; that is, she is conflicting with her image in the mirror. It is worth noting that the narrator undertakes a mirror journey that involves three phases through which Joan realizes her real self. To begin with, in the first phase, in her writing sessions; in front of the mirror, Joan looks at the reflection of the candles. She suddenly sees, "Infinite number of candles" (248). Joan goes closer to the reflection declaring, "I went into the mirror one evening and could not get out again. I was going to the corridor with the candle in my hand as usual, and the candle went out [...] and I was stuck there in the midst of darkness unable to move. I had lost sense of direction [...] I was suffocating" (242-43). In the second phase, through her heroine, Joan shows that her real - self interacts with her image in the mirror: "Felt her gaze being drown to the flame; her mind fluttered, fascinated, helpless as a moth her own reflection disappeared [...] further into the mirror she went, and further, till she seemed to be walking on the other side of the glass, in a land of distant shadows" (218). In the third phase, Joan plunges into the lake to put an end to her double reconnecting again with reality. In the real phase, Lacan mentions that the individual realizes the real traumatized self. In Joan's case, Atwood shows that Joan, after realizing her real self, Joan is no longer engulfed by psychosis. She recognizes that she is Joan Foster who lives in the real world in a physical body. Laura Stephenson maintains that "The mirror phase has been long been acknowledged as an important stage in the development of the subject" (Stephenson 2016, 79). Stephenson adds, "Mirrors are an appropriate prop for the depiction of psychosis given that they provide an image which functions as the vision- based manifestation of the emergence of the real in reality" $(2016,75)$.

Due to her schizophrenic case, Joan repetitively notes that her shadowy twin would end her life, "My dark twin, and my funhouse-mirror reflection. She was taller than I was, more beautiful, more threatening. She wanted to kill me and take my place" (273). Through the interplay between the fat lady's voices and her appearance in bodily form, Joan finally comprehends that during her childhood, she suffers from neglect, abandonment, and maltreatment and she has to come to terms with her past in order to live as a visible individual. In this context, Atwood uses the metaphor of flying to show that after coming to terms with her past, Joan, finally, gets rid of her psychic disorder, "That dark place is only a cocoon, we will rest there for a time, and after that we will emerge with beautiful wings; we will be butterflies, and fly up toward the sun" (114). 
Hearing Voices: A Corporeal Expression of Trauma in Margaret

Atwood's Lady Oracle

What is noticeable is that Atwood renders the concept of hearing voices problematic in Lady Oracle through literary techniques. Atwood deploys different literary techniques and stylistic forms to not only write about the character's life events, but also to shed light on Joan's consciousness. Sudhar Pandey explains the function of literary techniques as "the basic structures of human emotions and feelings demand suitable techniques and patterns of expression in the work of art" (qtd. in Sharma, 2008, 206). Sharma also notes that the literary technique is a tool through which the author grapples with the consciousness of the character $(2008,207)$. In accentuating the narrator's escapism from her past, Atwood blurs the borders between fiction and reality, between art and life. As an illustration, Atwood shows how Joan in the process of writing her gothic romance, Joan connects her life with the experiences of her protagonist in a way she fictionalizes her life arriving at the conclusion that her past memories haunt her wherever she goes. According to Godard, in Lady Oracle, "Atwood plays with the notion of distorting mirrors, convex, foregrounding here the central issue of the novel, that all reflections are distortions, all mimetic representations lie" $(1983,17)$. Importantly, through merging between the past and the present, and the use of flashbacks, Atwood evokes the character's memories to unfold again to her consciousness.

In Lady Oracle, Atwood also uses intertextuality as a way to focus on the psyche of Joan. In her Margaret Atwood's Fairy- Tale Sexual Politics (1993), Sharon Rose Wilson notes that Atwood uses previous literary works to challenge and to revise certain traditional ideas as the meaning of the self, "Some of the psychic pain that Atwood characters, notably Marian [The Edible Woman], Joan Foster [Lady Oracle] experience seems to derive from their unquestioning ingestion of old stories or an already written plot line that threatens to limit their life choices" (Wilson, 1993, 11). While Potts (1999, 281) declares that " Margaret Atwood's intertextuality is as the means of contesting the notions of authority [...] Atwood's narrative transgressions ultimately challenge yet, another by product of the Western world view: the traditional concept of the self". Atwood draws on traditional literary conventions to subvert certain ideas as the traditional meaning of the self.

Throughout her fiction, Atwood reworks the genre of fairy tales to highlight the psyche of her characters. Fairy tales are a main concern in the field of psychoanalysis. Freud, for instance, analyses Hoffmann's fairy tale of "The Sandman" to elaborate on his theory of “The Uncanny." Jung, too, has a significant contribution to the subject in Archetypes and the Collective Unconscious (1968) where he theorizes that fairy tales are part of the collective unconscious in a way that through fairy tales, individuals learn more about their psyches. Marie Louise Von Franz is a Jungian follower who emphasizes the meaning of fairy tales. In her book The Interpretation of Fairy Tales (1996), she maintains that fairy tales are not only associated with the psyche, but they are also expressed through symbols $(1996,62)$.

It seems that in Lady Oracle, Atwood draws upon Hans Christian Anderson's fairy tale of “The Little Mermaid" (1837). With its images of death, Anderson's fairy tale has influenced Atwood's creative writings, particularly in Lady Oracle. Atwood frequently alludes to "The Little Mermaid" constituting a parallel between her protagonist Joan and the heroine in the fairy tale. To begin with, both characters have a particular goal. In Anderson's tale, the little mermaid strives to gain a human soul while, in Atwood's 
Lecheheb, Al-Khawaldeh

novel, Joan wishes to reconstruct her true self. Secondly, the theme of sacrifice is present in both texts. In Anderson's tale, the little mermaid sacrifices her voice to have legs and a human soul as a way to dance with the prince. In Lady Oracle, Joan sacrifices to satisfy her husband. Wilson asserts that in Anderson's tale and Atwood's novels, women "Symbolically lose their eyes, tongues, heads, or hearts and bodies, hands, or feet in phallocentric culture" $(1993,122)$.

Atwood pushes the analogy between Joan and the little mermaid further; through the narrative, Joan, at the beginning, expects that, through marriage, girls are to be rescued by a prince. After her marriage, Joan realizes that "Those who got married too young, who had babies too early, who wanted princes and castles, ended up with cramped apartments and grudging husbands" (99). To clarify her point, Joan gives examples of fairy tales, in which girls fail and have tragic endings as Anderson's "The Little Mermaid." Joan declares, "I thought I had no soul; I just drifted around, singing vaguely, like the little mermaid in Anderson's fairy tale. In order to get a soul you had to suffer, you had to give something up" (235). Joan refers to the little mermaid's tragic end to understand more her relationship with her husband. In other words, the mermaid's destructive end in Anderson's fairy tale guides Joan to put an end to her unhealthy relation with her husband. Unlike the heroines in traditional fairy tales, Atwood's protagonist neither gives up her art nor sacrifices her soul for the sake of pleasing her husband. Joan rather empowers herself to be a whole entity.

\section{Conclusion}

The study ventures into establishing a connection between hearing voices and earlier childhood trauma in Atwood's Lady Oracle, in which Joan is imprisoned within her traumatic past memories that continue to forcibly live in her present, molding her language and behavior. Those memories materialize not only in the form of voices, but also in the medium of visible bodies, phantoms; which creates a sort of psychological disintegration and dissociation for the character. Building on the theoretical studies of Freud, Caruth, and Di Prete among others who point to corporeal projection of trauma through hallucinations and hearing voices, the exploratory nature of the study asserts the possibility that hallucinations and hearing voices serve the thematic function of enunciating childhood trauma in Atwood's Lady Oracle. 
Hearing Voices: A Corporeal Expression of Trauma in Margaret Atwood's Lady Oracle

\section{سماع الاصواتٍ :التعبير الجسدي للصدمة في رواية مارغريت \\ اتوود (السيدة اوراكل)}

$$
\text { قسم اللغة الانجليزية وآدابها، الجامعة الاردنية، الخوالدة، الاردن }
$$

\section{الملخص}

تهدف هذه الدراسة الى إعطاء العرض المرضي "سماع الأصوات" تصوراً أدبياً من خلال قراءة تحليلية لرواية (مارغريت اتوود) (السيدة اوراكل) (19V7). من خلال تسليط الضوء على التعاضد بين الجسد والصوت والصدمة، تفحص الدراسة بالتحديد كيف عادت الصدمة من طفولة بطلة الرواية للظهور عبر شقوق في وعيها، وذلك في صورة هلوسة وسماع أصوات خلال مرحلة الكبر. تهدف الدراسة أيضا الى استكثاف أسلوب (اتوود) في إثارة الجدل حول سماع الأصوات في روايتها موضوع الدراسة من أجل إبراز نفسية بطلتها. وتعتمد الدراسة في مناقشتها على نظريات (سيغموند فرويد) حول تمظهر

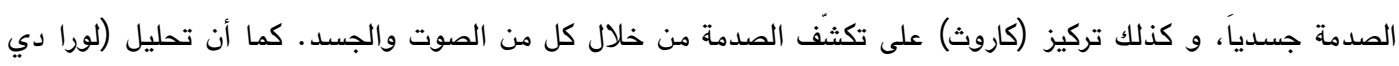
بريت) للتفاعل ما بين الأصوات المجسدة والهيئات الناطقة ذو صلة بموضوع الدراسة. الكلمات المفتاحية: ذكريات الطفولة، جسدية الصدمة، سماع الأصوات، مارغريت اتوود، السيدة اوراكل. 


\section{References}

Abraham, Nicolas and Nicholas Rand. 1987. Notes on the Phantom: A Complement to Freud's Metapsychology. Critical Inquiry 13 (2): 287- 292.

Anderson, Hans Christian. 1993. The Little Mermaid. New York: Henry Holt.

Andreasen, Nancy C and Carpenter William T. 1993. Diagnosis and Classification of Schizophrenia. Schizophrenia Bulletin National Institute and Mental Health 19 (2): 199- 214.

Atwood, Margaret. 1976. Lady Oracle. Great Britain: Virago.

Benjamin, Jessica. 1988. The Bonds of Love: Psychoanalysis, Feminism, and the Problem of Domination. New York: Pantheon Books.

Bleuler, Eugen and Jung CG. 1908. "Komplexe und Krankheitsursachen bei Dementia Praecox" ('Complexes and Etiology in Dementia Praecox'). Zentralblatt für Nervenheilkunde und Psychiatrie XIX: 220- 227.

Bleuler, Eugen. 1918. “Consciousness and Association.” (M. D. Eder Trans). In: Jung CG, ed. Studies in Word-Association: Experiments in the Diagnosis of Psychological Condition Carried out at the Psychiatric Clinic of the University of Zurich. New York: M.D.Eder: 266-296.

Bleuler, Eugen. 1950. Dementia Praecox or Group of Schizophrenias. New York: International Universities Press.

Caruth, Cathy. 1996. Unclaimed Experience: Trauma, Narrative and History. Baltimore: Johns Hopkins University Press.

Cutting, John C. 1989. Hearing Voices: May Be Normal But Happens Most Commonly in Schizophrenia and Alcoholic Hallucinations. British Medical Journal 298 (6676): 769- 770.

Delillo, Don. 2001. The Body Artist. New York: Scribner.

Di Prete, Laura. 2006. Foreign Bodies: Trauma, Corporeality and Textually in Contemporary American Fiction. New York: Routledge.

Di Prete, Laura. 2005. Don Delillo's The Body Artist: Performing the Body, Narrating Trauma. Contemporary Literature 46 (3): 483- 510.

Doane, Janice and Hodges Devon. 1992. From Klein to Kristeva: Psychoanalytic Feminism and the Search for the Good "enough" mother. Ann Arbor: University of Michigan Press.

Felman, Shoshana and Laub Dori. 1992. Testimony: Crises of Witnessing in Literature, Psychology, and History. New York: Routledge.

Franz, Marie Louise Von. 1996. The Interpretation of Fairy Tales. Revised Ed. London: Shambhala.

Freud, Sigmund and Joseph Breuer. 2004. Studies in Hysteria. Trans. Nicola Luckhurst. New York: Penguin Books.

Freud, Sigmund. 2003. Beyond the Pleasure Principle and Other Writings. Trans. John Reddick. New York: Penguin Books.

Gautam, Vijeta. 2012. Transformation of the Protagonist in Margaret Atwood's Lady Oracle. International Journal of Humanities and Social Science 2 (3): 233- 36.

Gibson, William M. 1951. Metaphor in the Plot of 'The Ambassadors'. The New England Quarterly 24 (3): 291-305. 
Hearing Voices: A Corporeal Expression of Trauma in Margaret

Atwood's Lady Oracle

Gilman, Sander L. 2019. Disease and Representation: Images of Illness from Madness to AIDS. London: Cornell University Press.

Godard, Barbara. 1983. My Mother, My Self: Strategies for Subversion in Atwood and Herbert. Essays on Canadian Writing 426: 13- 44.

Gogol, Nikolai. 1987. Diary of a Madman. In Government Inspector and Other Works. Great Britain: Wordsworth Classics: 435 - 453.

Horvitz, Deborah. 2000. Literary Trauma: Sadism, Memory, and Sexual Violence in American Women's Fiction. New York: Suny Press.

Hutcheon, Linda. 1988. The Canadian Postmodern: A Study of Contemporary English Canadian Fiction. Toronto: Oxford University Press.

Irigaray, Luce. 1991. "The Bodily Encounter with the Mother." In The Irigaray Reader, (Ed) Margaret Whitford. Oxford: Blackwell.

James, Henry. 1903. The Ambassadors. New York: Harper and Brothers.

Jung, Carl Gustav. 1960. The Psychology of Dementia Praecox. (Trans.R.F.C. Hull). In: The Psychogenesis of Mental Disease. London: Routledge \& Kegan Paul: 3 -151.

Jung, Carl Gustav. 1968. The Archetypes and the Collective Unconscious. Translated by R. F.C Hull. New York: Routledge.

Klein, Melanie. 1997. Some Reflections on the Oresteia: Envy and Gratitude and Other Works 19461963. London: Vintage.

Kraepelin, Emil. 1896. Psychiatry: A Textbookfor Students and Physicians. ${ }^{\text {th }}$ Edition. Barth: Leipzig.

Lacan, Jacques. 1977. Écrits. Trans, Alan Sheridan. New York: Routledge.

Lacapra, Dominick. 2001. Writing History, Writing Trauma. Baltimore: Johns Hopkins University Press.

Laing, Ronald David. 1960. The Divided Self: An Existential Study in Sanity and Madness. London: Penguin Books.

Larkin, Warren and Anthony P. Morrison. 2006. (Eds). Trauma and Psychosis: New Directions for Theory and Therapy. New York: Routledge.

Lecker, Robert. 1981. "Janus through the Looking Glass: Atwood's First Three Novels." In Arnold Davidson and Cathy Davidson (Eds). The Art of Margaret Atwood: 177- 202.

Leverage Paula, Mancing Howard, Schweickert Richard, William Jennifer Marston, (Eds). 2011. The Theory of Mind and Literature. Indiana: Purdue University Press.

Mc Kague, Meredith; Mc Anally, Ken I; Puccio, Francis; Bendall, Sarah; Jackson, Henry J.H. 2012. Hearing Voices Inside and Outside the Head: Spatial Source Monitoring in Participants Prone to Auditory Hallucinations. Gognitive Neuropsychiatry 17 (6) : 506-526.

Morel, Bénédict Augustin. 1860. Traité des Maladies Mentales. [Treating Mental Illnesses] Paris: Victor Masson.

Nayani, Tony H. and Anthony S. David. 1996. The Auditory Hallucination: A Phenomenological Survey. Psychological Medicine 26: 177- 189. 
Lecheheb, Al-Khawaldeh

Noll, Richard. 2011. American Madness: The Rise and Fall of Dementia Praecox. London: Harvard University Press.

Ponty, Merleau Maurice. 2002. The Phenomenology of Perception. New York: Routledge.

Potts, Donna L. 1999. “The Old Maps Are Dissolving:” Intertextuality and Identity in Atwood's The Robber Bride. Tulsa Studies in Women's Literature: 18 (2): 281-298.

Rashkin, Esther. 1992. Family Secrets and the Psychoanalysis of Narrative. Princeton: Princeton University Press.

Rashkin, Esther. 2011 Reading the Mind, Reading the text, Reflective Functioning, Trauma and Literature, and the Task of the Psychoanalytic Critic. American Imago. From Freud to Literature 68 (1): $37-48$.

Rose, Jacqueline. 1996. Of Knowledge and Mothers: On the Work of Christopher Bollas. Gender and Psychoanalysis 1 (4): 411- 27.

Rosenberg, Jerome, H. 1984. Margaret Atwood. Boston: Twayne Press.

Sharma, Priya. 2008. Technique in the Selected Novels of Margaret Atwood. International Journal of English Language, Literature, and Translation Studies 5 (2): 206-213.

Stephenson, Laura. 2016. Mirror: Mirror on the Wall: A Dancer, her Psychosis, and the Black Swan of the Real. Medians 16 (2): 65-82.

Stone, Alan A and Sue Smart Stone. 1966. The Abnormal Personality through Literature. Englewood Cliffs: Prentice.

Tal, Kali. 1996. Worlds of Hurt: Reading the Literatures of Trauma. New York: Cambridge University Press.

Thraenhardt, Bettina. 2007. Hearing Voices.” Scientific American Mind 17 (6): 74-79.

Wilson, Sharon Rose. 1993. Margaret Atwood's Fairy- Tale Sexual Politics. Mississippi: University Press of Mississippi.

Woodhead Kate and Wicker Paul. 2005. A Textbook of Perioperative Care. London: Elsevier Churchill Livingstone. 